Nordisk Tidsskrift for Kriminalvidenskab 2007

\title{
DEN EUROPEISKA ARRESTERINGSORDERN I SVERIGE \\ - MED NÅGRA UTBLICKAR TILL DANMARK OCH FINLAND
}

Av professor Per Ole Träskman

The European arrest warrant, which emanates from the intensified EU efforts to combat crime, was introduced as a new legal tool for use by EU Member States in connection with the framework decision of the Council of Ministers from June 13, 2002. In Sweden, as well as in Denmark and Finland, the regulations of the framework decision were implemented through new national legislation. This article focuses on the Swedish legislation, but also provides some comparative comments regarding the Danish and the Finnish situations. Previous guidelines for transferring suspects or offenders by use of extradition are compared with new practices - especially in regard to legal rights and legal security. The European arrest warrant has quickly become an important and frequently used measure which the authorities laud as a significant part of a modern and efficient European crime prevention scheme. Viewed from a legal rights perspective the evaluation becomes somewhat more negative. From that perspective, implementation of the European arrest warrant can be seen as just one more sign of the ongoing shift within the EU towards a new paradigmatic model for adjudication and criminal proceedings. The leading paradigm is no longer a legal rights model with emphasis on legal protections and security but rather a control model with emphasis on efficiency.

\section{EU och brottsligheten}

Särskilt sedan slutet av 1990-talet har bekämpandet av brottsligheten legat högt på EU:s agenda. I officiella dokument och uttalanden av ansvariga politiker motiveras detta med att särskilt den organiserade och/eller den gränsöverskridande brottsligheten upplevs som och utgör ett allvarligt hot. En effektiv kontroll av brottsligheten bedöms därför vara nödvändig för att realisera EU:s målsättning om ett område karaktäriserat av frihet, rättvisa och säkerhet. För att säkerställa effektiviteten bör - anför man - väsentliga delar av brottskontrollen vara gemensam. ${ }^{1}$ Gemensamma åtgärder har också vidtagits på flera områden. Då det gäller de straffrättsliga bestämmelserna har en harmonisering av lagstiftningen i medlemsstaterna genomförts särskilt genom ett antal rambeslut. ${ }^{2}$ På straffprocessens område har en del ansträngningar gjorts för att garantera en rättvis rättegång

\footnotetext{
* Title in English: The European Arrest Warrant. Original in Swedish.
} 
och för att säkerställa att en brottsanklagad person tillförsäkras ett värdigt försvar. ${ }^{3}$ Arbetet för att höja brottskontrollens effektivitet har emellertid framför allt skett genom åtgärder för att underlätta den internationella rättsliga hjälpen och det övriga brottskontrollerande samarbetet dels mellan medlemsstaterna och dels mellan EU, EU-staterna och stater utanför unionen. ${ }^{4}$ Bland dessa åtgärder för att underlätta den internationella rättsliga hjälpen framhävs ofta den europeiska arresteringsordern som en framgång. ${ }^{5}$

I denna artikel granskas den europeiska arresteringsordern och dess implementering i Sverige. För att möjliggöra en viss nordisk jämförelse görs också vissa utblickar till lagstiftningen om arresteringsordern i Danmark och i Finland.

\section{Inledning - arresteringsorderns bakgrund}

Den Europeiska arresteringsordern infördes som en ny form för rättslig hjälp mellan den Europeiska unionens medlemsstater genom Rådets rambeslut av den 13 juni 2002. Detta rambeslut betecknades från första början som en mycket central åtgärd för att realisera det europeiska området med frihet, säkerhet och rättvisa. I Sverige följde man tropp för att nå detta område så hurtigt som möjligt genom att implementera rambeslutets bestämmelser genom ny lagstiftning, särskilt lag (2003:1156) om överlämnande från Sverige enligt en europeisk arresteringsorder. Innehållet $\mathrm{i}$ rambeslutet om arresteringsordern hade dock i verkligheten redan godkänts tidigare - i själva verket före Europeiska Rådets antagande av rambeslutet - genom riksdagens godkännande av rambeslutet den 22 maj 2002. ${ }^{6}$

På motsvarande sätt implementerades rambeslutet i den nationella lagstiftningen i Danmark och i Finland, men här skedde det genom ändring av lagarna om utlämning. I Danmark kompletterades utlämningslagen (udleveringsloven) med två nya kapitel, ${ }^{7}$ och i Finland utarbetades en ny lag, lag om utlämning för brott mellan Finland och de övriga medlemsstaterna i Europeiska unionen (30.12.2003/1286).

Rambeslutets historiska betydelse tillskrivs det faktum att det var den första konkreta lagstiftningsåtgärden på det straffrättsliga området för att inom Europeiska unionen förverkliga principen om ömsesidigt erkännande av domar och andra rättsliga avgöranden. I den europeiska jargongen hade vid tidpunkten för införandet av arresteringsordern principen om ömsesidigt erkännande av domar och andra rättsliga avgöranden under några års tid kallats en "hörnsten" i det rättsliga samarbetet. Det politiska mål som uppställts var inte bara att skapa ett område av frihet, säkerhet och rättvisa, utan också att åstadkomma ett europeiskt rättsområde där alla Europeiska unionens medlemsstater med tiden skall utgöra en enda jurisdiktion. ${ }^{8}$

Vad man ville åstadkomma genom ordningen med en europeisk arresteringsorder var ett förfarande varigenom man snabbt kunde få en för brott misstänkt eller dömd person från en medlemsstat till en annan. I preambeln till rambeslutet 
konstaterar man att det formella utlämningsförfarandet bör avskaffas bland medlemsstaterna när det gäller "personer som är på flykt undan rättvisan" efter att ha fått sin slutgiltiga dom, och förfaranden för utlämningsärenden påskyndas vad gäller "personer som är misstänkta för brott".

Införandet av den europeiska arresteringsordern rättade utan tvivel till ett reellt problem. Det traditionella förfarandet för utlämning för brott har varit både komplicerat och tidsödande. De internationella instrument, framför allt skilda utlämningskonventioner och traktat mellan stater, ${ }^{9}$ har inte gett en tillräcklig legal grund för ett rättssäkert, effektivt och tillräckligt snabbt förfarande för att förflytta en för brott misstänkt eller dömd person från en jurisdiktion till en annan. En snabbt rättsligt förfarande ligger både i myndigheternas och i den för brott anklagades intresse.

I preambeln till rambeslutet fastslås att de nuvarande förfarandena för utlämning är komplicerade och riskerar att ge upphov till förseningar. Detta kan enkelt avhjälpas genom införandet av ett nytt förenklat system för överlämnande av dömda eller misstänkta personer för verkställighet av domar eller för lagföring. Det konstateras att det inte längre i det nya Europa finns något behov för utlämning mellan stater, men ett behov av ett system för överlämnande mellan likvärdiga rättsliga myndigheter. Detta system är en tillbyggnad till det europeiska systemet för rörlighet. Förutom att gälla en fri rörlighet för varor, tjänster, kapital och människor, skall den fria rörligheten inom Europa också omfatta en fri rörlighet för straffrättsliga avgöranden, såväl preliminära som slutliga. En sådan fri rörlighet betecknas som ett centralt inslag i ett område med frihet, säkerhet och rättvisa.

I ett europeiskt perspektiv är intentionerna bakom och ambitionerna med en ordning för en europeisk arresteringsorder således goda. Finns det då överhuvudtaget några goda skäl för att ställa sig kritisk till den europeiska arresteringsordern? Är det så att "rättvisans prins" i arresteringsordern fick den goda, riktiga Askungen till god maka och evigt stöd, eller är det möjligen så att arresteringsordern i själva verket är en av de bedrägliga styvsystrarna som lurade sig till rättvisans prins genom att klippa bort någon tå och skära av en häl för att få sin fot att passa i politikens lämpliga sko?

\section{Vad avses med den "europeiska arresteringsordern"?}

Med en europeisk arresteringsorder avses ett rättsligt avgörande, utfärdat av en rättslig myndighet $i$ en medlemsstat $i$ Europeiska unionen, som innebär en begäran om att en rättslig myndighet $i$ en annan sådan stat skall gripa och överlämna en eftersökt person för lagföring eller för verkställighet av en frihetsberövande påföljd..$^{10}$ 
Syftet med ordningen med en europeisk arresteringsorder är att åstadkomma ett förfarande som möjliggör att en för brott misstänkt eller dömd person snabbt kan överlämnas från en EU-stat till en annan. Överlämnandet skall ske genom åtgärder som vidtas av jämbördiga myndigheter i berörda stater inom ramen för deras egen behörighet, och utan inblandning i sak av andra rättsliga eller politiska organ. Fråga är inte om ett förfarande där en person på traditionellt sätt utlämnas för brott från en stat till en annan, utan om ett förfarande där en person överlämnas från en myndighet till en annan, inom ett rättsligt område som i väsentliga avseenden betecknas som en enda jurisdiktion. Fråga är inte om ett förfarande där en myndighet genom en in casu-prövning skall godkänna och acceptera ett rättsligt avgörande som en främmande myndighet har tagit, utan om ett förfarande som primärt bygger på att varje myndighet skall erkänna den rättsliga riktigheten och giltigheten av behöriga myndigheters alla avgöranden - också om dessa avgöranden har fattats med stöd av en annan lagstiftning än den som binder myndigheten ifråga. Nyckelordet är ömsesidigt erkännande av rättsliga avgöranden, också om dessa avgöranden har träffats med stöd av en främmande lag. ${ }^{11}$

För att uppnå syftet med den europeiska arresteringsordern var det nödvändigt att i flera väsentliga avseenden ändra på det förfarande som traditionellt har gällt för utlämning för brott, särskilt då det gäller den prövning som har förutsatts för att uppfylla sådana rättssäkerhetsgarantier som uppfattats vara nödvändiga. Det traditionella utlämningsförfarandet kan karaktäriseras som en process med många faser, där olika experter har ansvaret för varje skild fas, och där saken förpassas till följande fas först då experten utfört sitt eget arbete och gett sin garanti för att produkten är tillräckligt god för att bearbetas vidare. I den sista fasen kontrolleras arbetet i dess helhet, och bara om resultatet, efter en individuell prövning, är tillfredsställande till alla delar, avslutas processen genom ett slutligt avgörande. Överlämningsförfarandet enligt ordningen för den europeiska arresteringsordern kan däremot jämföras med mekanisk massproduktion. De som har ansvar för senare delar av processen skall egentligen inte alls kontrollera vad som har skett tidigare - de skall automatiskt erkänna att det tidigare arbetet är riktigt utfört och att produkten är tillräcklig god.

Ordningen för den europeiska arresteringsordern bygger på ett förfarande med direkt kontakt mellan de nationellt behöriga myndigheterna. En rättslig myndighet $i$ en medlemsstat som önskar att en eftersökt person skall gripas och överlämnas till denna stat för lagföring eller för verkställighet av en frihetsberövande påföljd, utfärdar ett rättsligt avgörande som innehåller en sådan begäran. Denna arresteringsorder får skickas genom Schengens informationssystem (SIS) eller något annat system för eftersökning av brottsmisstänkta personer, eller alternativt - om det är känt var den eftersökte befinner sig - till behörig myndighet. Behörig 
myndighet är i Sverige behörig åklagare, ${ }^{12}$ medan Finland valt en ordning där bara vissa häradsåklagare på några större orter (Helsingfors, Kuopio, Tammerfors och Uleåborg) är behörig..$^{13}$ I Danmark valde man att bibehålla justitieministeriet som judiciell myndighet också då det gäller den europeiska arresteringsordern. ${ }^{14}$

Den myndighet (i Sverige åklagaren) som har mottagit en arresteringsorder, beträffande en person vars uppehållsort är känd, skall omedelbart inleda en utredning om gripande och överlämnande. I detta fall finns det inte något utrymme för en diskretionär prövning av om en utredning verkligen är befogad. En utredning skall också, på försorg av de behöriga myndigheterna i den medlemsstat där den som eftersökts befinner sig, ske i det fall, då arresteringsordern utsänts utan tillräcklig kunskap om var den eftersökte befinner sig, så snart som det framkommer var han/hon kan påträffas. Denna inledande utredning skall avse frågan om det finns förutsättningar till överlämnande. ${ }^{15}$ Den som eftersöks och som gripits med stöd av en europeisk arresteringsorder har rätt till juridiskt biträde och tolk. ${ }^{16}$ Enligt den svenska lagen om överlämnande från Sverige enligt en europeisk arresteringsorder $(8 \S)$ skall en offentlig försvarare förordnas för den eftersökte om han eller hon begär det. Detsamma skall alltid ske då den eftersökte är under arton år eller annars bedöms vara i behov av en försvarare. ${ }^{17}$

Rambeslutet om den europeiska arresteringsordern anger inte vilken rättslig myndighet som skall vara nationellt behörig att utfärda respektive att verkställa en europeisk arresteringsorder. ${ }^{18}$ Medlemstaterna själva har rätt att bestämma vilken myndighet det är som har denna behörighet. Sverige har valt att ge beslutanderätten då det gäller överlämnande av en person från Sverige till tingsrätten. Enligt lagen om överlämnande från Sverige enligt en europeisk arresteringsorder (5 kap.) skall en begäran om överlämnande och därmed sammanhängande frågor prövas av tingsrätt. Det beslut som tingsrätten fattar får - med vissa undantag - överklagas enligt allmänna regler om överklagande av domstols beslut i brottmål. I Danmark är det justitieministeriet som är den beslutande myndigheten, men den eftersökte har rätt - i det fall att justitieministeriet bifaller begäran om överlämnande - att få frågan prövad vid domstol..$^{19}$ I Finland tas besluten av vissa utpekade domstolar, nämligen tingsrätterna i Helsingfors, Kuopio, Tammerfors och Uleåborg. ${ }^{20}$

Den utredning som görs med anledning av en utfärdad arresteringsorder skall klarlägga om det finns förutsättningar för överlämnande av en eftersökt person. Vad som skall eftersträvas är ett samtycke av den eftersökte personen. Enligt rambeslutet (artikel 13) skall det - och uppenbarligen i ett tidigt skede under utredningsförfarandet (se artikel 11) - klarläggas om den eftersökte samtycker till att bli överlämnad. Enligt den svenska lagen om överlämnande ( 9 §) skall den eftersökte så snart det kan ske tillfrågas om han eller hon samtycker till överlämnande. I sådant fall skall den eftersökte också tillfrågas om han eller hon medger 
att i den utfärdande medlemsstaten lagföras eller straffas för gärningar som har begåtts före överlämnandet, men som inte omfattas av arresteringsordern. Enligt rambeslutet (artikel 13:4) skall ett samtycke i princip vara oåterkalleligt. Enligt den svenska lagen skall den eftersökte upplysas om innebörden av att samtycke och medgivande lämnas, och ett återkallande kan också få rättslig betydelse. En återkallelse av samtycket skall beaktas om den görs innan rätten har meddelat beslut i fråga om överlämnande.

Enligt den danska lagen skall den eftersökte under undersökningen av om ett överlämnande skall ske informeras om möjligheten till att samtycka till överlämnandet. ${ }^{21}$ De finska bestämmelserna är i detta avseende något avvikande och något utförligare. Den eftersökte skall, sedan rätten underrättat den eftersökte om samtyckets innebörd, personligen vid tingsrättens sammanträde meddela om han eller hon samtycker till överlämnandet. Samtycket kan senare återkallas och om detta sker skall ärendet behandlas på nytt. ${ }^{22}$ Också om samtycke föreligger kan domstolen förvägra överlämnande om den eftersökte är åtalad för ifrågavarande gärning i Finland eller om den helt eller delvis har begåtts i Finland eller ombord på finskt fartyg eller luftfartyg. ${ }^{23}$

En person som eftersöks med stöd av en arresteringsorder skall enligt huvudregeln alltid bli berövad sin frihet. Enligt rambeslutet (artikel 12) skall den eftersökte gripas och vid behov häktas. Enligt den svenska lagen om överlämnande från Sverige enligt en europeisk arresteringsorder (5 §) skall den eftersökte anhållas av den åklagare som utför den förberedande utredningen. De enda undantagen som berättigar till att inte anhålla är att det från första början kan antas att förutsättningar för ett överlämnande saknas, eller att det inte finns någon risk för att den eftersökte avviker eller på annat sätt undandrar sig ett överlämnande. Trots att en risk för flyktfara finns skall anhållande dock ske om det finns en kollusionsfara. ${ }^{24}$ I vissa fall kan ett frihetsberövande ersättas med ett reseförbud. ${ }^{25}$

Beslutet om överlämnande av en eftersökt person skall ske i brådskande ordning - alltså "med skyndsamhet". ${ }^{26}$ Enligt den svenska lagen (5 kap. 2 §) skall enligt huvudregeln tingsrätten meddela sitt beslut i frågan senast trettio dagar efter det att den eftersökte gripits. Om den eftersökte samtycket till överlämnandet skall beslutet meddelas senast tio dagar efter det att samtycket har getts. Tingsrätten skall för prövningen av frågan om överlämnande hålla en förhandling. En förhandling behöver dock inte hållas om det är uppenbart att överlämnande inte skall beviljas, om den eftersökte samtycker till överlämnande eller om han eller hon begär att ärendet avgörs på handlingarna. ${ }^{27}$

Presumtionen är att en eftersökt person skall överlämnas till den stat som utfärdat arresteringsordern. Enligt rambeslutets artikel 1 stycke 2 "skall [medlemsstaterna] verkställa varje europeisk arresteringsorder i enlighet med principen 
om ömsesidigt erkännande [...]", och enligt den svenska lagen ${ }^{28}$ skall den som eftersöks enligt en arresteringsorder och som anträffas i Sverige [...] överlämnas till den utfärdande medlemsstaten.

Principen om ömsesidigt erkännande innebär att den behöriga myndigheten i den stat som mottagit en begäran om överlämnande inte skall genomföra någon prövning $i$ sak av den gärning som ligger till grund för arresteringsordern eller av den eftersöktes skuld till denna gärning. Vad som skall framgå av arresteringsordern är bara viss information om den eftersöktes identitet och nationalitet samt viss information om den gärning eller det rättsliga beslut som ordern grundas på. Då det gäller överförande av en eftersökt person till Sverige för verkställighet av en sådan frihetsberövande påföljd som inte kan verkställas i Sverige utan omvandling anges uttryckligen att rätten i ny dom skall bestämma en frihetsberövande påföljd som motsvarar den utländska påföljden, utan att prövning utsträcks till att också omfatta frågan om den som döms verkligen har begått gärningen och hur denna skall bedömas. ${ }^{29}$

Ordningen med en europeisk arresteringsorder bygger således i stor utsträckning på ett krav på snabbhet och effektivitet. För att uppfylla dessa krav förutsätts det att förfarandet är standardiserat, med regler som bygger på starka presumtioner om vilket avgörandet skall vara. Möjligheterna till in casu-prövning med beaktande av individuella omständigheter minimeras starkt för att undvika undantagslösningar som försenar processen eller minskar effektiviteten. Effektivitetsbedömningen bygger härvid på antagandet att den eftersökte är skyldig och att han eller hon egentligen bara är en person som "är på flykt undan rättvisan".

\section{Hinder för utlämning och hinder för överlämnande}

Vid utlämning för brott har man traditionellt uppställt vissa villkor som skall vara uppfyllda för att en utlämningsbegäran skall kunna bifallas. Man har också formulerat vissa hinder för utlämning och accepterat att vissa villkor uppställs för utlämningen. Vilka dessa förutsättningar och hinder är, och vilka villkor som kan uppställas, varierar beroende på mellan vilka stater utlämningen skall äga rum och vilka rättsliga normer som skall tillämpas vid utlämningen. ${ }^{30}$

Ett traditionellt villkor för utlämning är att kravet på dubbel straffbarhet är uppfyllt. Enligt lagen (1957:668) om utlämning för brott (4 §) får utlämning beviljas endast om den gärning för vilken utlämning begärs motsvarar brott, för vilket enligt svensk lag är föreskrivet fängelse i ett år eller mer ${ }^{31}$ Då utlämning begärs för verkställighet av straff förutsätts det att påföljden utgör minst frihetsstraff i fyra månader eller annat omhändertagande på anstalt under motsvarande tid. En annan förutsättning för utlämning är att det finns en tillräckligt övertygande utredning om att den som begärs utlämnad verkligen är skyldig till brottet. Denna 
skuldfråga skall kunna prövas i den stat som mottagit begäran om utlämning. Enligt gällande utlämningslag "må utlämning ej beviljas, med mindre domen stödjes av utredningen och ej heller eljest föranleder allvarlig erinran." ${ }^{32} \mathrm{Om}$ dom angående gärningen ej har meddelats i den främmande staten, skall framställningen om utlämning grundas på beslut om häktning, som meddelats av behörig myndighet i den främmande staten. ${ }^{33}$

De traditionella hindren för utlämning hänför sig både till den anklagades/ dömdes person, till brottets karaktär och till de omständigheter som råder i den stat som har begärt utlämning.

Med avseende på brottet är den traditionella regeln att utlämning för militärt brott inte är möjligt. ${ }^{34}$ Också då det aktuella brottet är ett politiskt brott föreligger ett utlämningshinder. ${ }^{35}$ Vissa tidigare rättsliga beslut omöjliggör också utlämning. Ett sådant beslut kan vara ett beslut i Sverige om åtalsunderlåtelse eller vissa domstolsbeslut som innebär att förbudet mot dubbel bestraffning på grund av res judicata- regeln aktualiseras. Utlämning är inte heller möjlig då åtalspreskription har inträffat enligt svensk rätt, eller då enligt svensk rätt straff för brottet skulle vara förfallet. ${ }^{36}$

Då det gäller den anklagades eller dömdes person utgör det av tradition ett utlämningshinder att personen är medborgare i den stat som mottagit utlämningsbegäran. ${ }^{37}$ Egna medborgare utlämnas inte. I vissa fall har gruppen "egna medborgare" också utsträckts till främmande statsmedborgare. I Sverige - och i de andra Nordiska staterna - har detta t.ex. skett i samband med tolkningen och tillämpningen av den Europeiska utlämningskonventionen. Enligt en deklaration avses med "svensk medborgare" i detta fall - förutom svenska medborgare - och utlänningar fast bosatta i Sverige, också medborgare i Danmark, Finland, Island och Norge, samt utlänningar bosatta i någon av dessa stater.

Av humanitära skäl är utlämning inte möjlig av vissa svaga personer eller personer som befinner sig i en utsatt position. Enligt utlämningslagen "må utlämning ej beviljas, om på grund av den avsedda personens ungdom, hälsotillstånd eller personliga förhållanden i övrigt [...] finnes uppenbart oförenlig med humanitetens krav." ${ }^{38}$ Bedömningen skall i detta fall vara individuell och därvid skall också beaktas gärningens beskaffenhet och den främmande statens intresse av att utlämning beviljas.

Då det gäller förhållandena $i$ den stat som har begärt utlämning och den behandling som kan förväntas av den person vars utlämning begärs i denna stat uppställs först och främst risken för förföljelse som ett utlämningshinder. Utlämning får inte ske om den person vars utlämning begärs på grund av sin härstamning, tillhörighet till viss samhällsgrupp, religiösa eller politiska uppfattning eller eljest på grund av de politiska förhållandena i den stat som har begärt utlämning löper 
risk att där utsättas för förföljelse, som riktar sig mot hans liv eller frihet eller eljest är av svår beskaffenhet. Detta utlämningshinder utsträcks också till det fall att vederbörande person i den stat som begär utlämning saknar trygghet mot att bli sänd till stat, i vilken han löper en sådan risk för förföljelse..$^{39}$

Vissa av de villkor som kan - eller bör - uppställas för att bevilja utlämning, gäller uttryckligen behandlingen av den person, som utlämningsbegäran avser, $\mathrm{i}$ den stat som begär utlämning. Det viktigaste av dessa villkor gäller dödsstraff. Som villkor skall alltid uppställas att den som utlämnas inte får straffas med döden för brottet. Andra villkor är att vederbörande person inte får åtalas för brottet vid en tillfällig domstol eller vid en domstol som bara finns till för särskilda undantagsförhållanden. Villkor kan också uppställas med stöd i den s.k. specialitetsregeln. Den som utlämnas får inte, utan särskilt medgivande, i den stat som begärt utlämning åtalas eller straffas för annat brott som begåtts före utlämningen än det som omfattas av begäran om utlämning. ${ }^{40}$

Då det gäller överlämnande av en person enligt en europeisk arresteringsorder är förutsättningarna för överlämnande, hindren mot överlämnande och de möjliga villkor som kan uppställas vid överlämnandet i flera avseenden väsentligen andra än vid utlämning för brott. ${ }^{41}$ Skillnaderna mellan utlämning för brott och överlämnande med stöd av en arresteringsorder är ett resultat av medvetna, målinriktade politiska beslut. Det intressanta är vad det är som egentligen styr dessa beslut och vilken rättspolitisk ideologi det är som dessa beslut grundas på.

Vissa av skillnaderna kan förklaras enkelt med hänvisning till hela avsikten med arresteringsordern och den politiska och rättsliga kontext i vilken den skall tillämpas. Men detta betyder inte nödvändigtvis att den reglering som rambeslutet om den europeiska arresteringsordern utgör också bör accepteras utan kritiska invändningar.

Den grundläggande utgångspunkten för hela ordningen med en europeisk arresteringsorder bygger - som konstaterat - på en princip om ömsesidigt erkännande av domar och andra rättsliga beslut. Huvudregeln är därför väldigt enkel och klar: "Den som eftersöks enligt en arresteringsorder, och som anträffas i Sverige (eller i en annan EU-stat), skall överlämnas till den utfärdande medlemsstaten." I vissa undantagsfall finns det dock hinder som medför att överlämnande inte skall ske.

Regleringen av vilka dessa hinder är, som innebär att överlämnande inte får ske, eller att överlämnande kan vägras, är tämligen komplicerad och inte särskilt användarvänlig, om man beaktar att ordningen bygger på att den förberedande utredningen skall göras av en allmän åklagare och beslutet tas av en tingsrätt. ${ }^{42}$ Vissa av hindren mot överlämnande anges explicit i rambeslutet om en europeisk arresteringsorder, men bestämmelserna om detta är inte alltid explicit formulerade 
i en särskild artikel, utan ofta framgår de bara ur någon av rambeslutets beaktandesatser. I den nationella svenska rätten har vissa av hindren mot överlämnande intagits i lagen om överlämnande från Sverige enligt en europeisk arresteringsorder, men inte heller i detta fall framgår alla hinder explicit i lagen. Vad som också skall beaktas är Fördraget om Europeiska unionen samt andra internationella fördrag och då särskilt Europeiska konventionen om mänskliga rättigheter och de tilläggsprotokoll till denna som gäller som lag. Ytterligare skall medlemstatens egen konstitution beaktas för att avgöra vilka hinder som kan eller bör uppställas som hinder för överlämnande. I Sverige innebär detta att särskilt regeringsformen, tryckfrihetsförordningen och yttrandefrihetsgrundlagen skall beaktas vid prövningen av om ett överlämningshinder föreligger. Det hela kompliceras ytterligare av att vissa av överlämningshindren är absoluta, medan andra är fakultativa.

Vissa av hindren mot överlämnande kan förklaras med en hänvisning till den straffrättsliga legalitetsprincipen och den traditionella uppfattningen om att kontrollen av brottslighet i grunden är en inre angelägenhet för en självständig stat. Detta gäller framför allt det hinder som innebär att överlämnande inte skall ske $i$ ett fall då gärningen helt eller delvis har ägt rum i Sverige (brottets gärningsort är Sverige), och inte motsvarar brott enligt svensk lag (gärningen är alltså tillåten i Sverige). ${ }^{43}$ Enligt förarbetena bör en utgångspunkt vara att överlämnande inte får ske för gärningar som har ägt rum i Sverige, om de inte är straffbara enligt svensk lag och heller inte skulle kunna leda till åtal i Sverige. Det är naturligt att överlämnande för en gärning som har ägt rum i Sverige inte bör kunna ske i större utsträckning än det hade varit möjligt att här i landet lagföra för gärningen. ${ }^{44}$

Läget blir emellertid ett annat så snart gärningen också är straffbar som brott enligt svensk lag. I detta fall bör överlämnande kunna ske också för gärningar som helt eller delvis har ägt rum i Sverige. Om en gärning har ägt rum i Sverige skall visserligen som regel också lagföringen ske här, men om denna gärning har anknytning till brottslighet i andra medlemsstater, bör det dock i de allra flesta fall också finnas förutsättningar för att överföra lagföringen dit. Det är då rimligt att det även finns förutsättningar att bistå med överlämnande trots att gärningen har ägt rum i Sverige. ${ }^{45}$

Det avstående från kravet på dubbel straffbarhet, som i flera fall har skett inom ordningen för en europeisk arresteringsorder, innebär att överlämnande antingen bör eller får ske i flera sådana fall, då gärningen inte motsvarar ett brott enligt svensk lag, och lagföring och straff för gärningen därför är utesluten i Sverige enligt svensk rätt. Denna fråga behandlas närmare senare. Också vissa fall, då straffansvar för en gärning inte kan utdömas i Sverige, eller då man genom ett rättsligt beslut har bestämt att lagföring och bestraffning av en brottslig gärning inte skall ske, bör (eller kan) utgöra överlämningshinder. Det är tämligen själv- 
skrivet att överlämnande inte får beviljas för en gärning som har ägt rum innan den eftersökte har fyllt femton år. ${ }^{46}$

Med hänvisning till den historiska traditionen då det gäller utlämning för brott, och kraven på rättssäkerhet är det också befogat att kunna vägra överlämning då saken redan har blivit avgjord genom ett rättsligt beslut. När det rör sig om tidigare beslut som gäller samma brottsliga gärning är det också för överlämnande med stöd av en arresteringsorder ett hinder för överlämnande att det i den stat som mottagit framställningen har meddelats ett beslut om att inte åtala för gärningen. ${ }^{47}$ Två fall som gäller en res judicata-situation uppställs - med hänvisning till ne bis in idem-regeln - som hinder för överlämnande. Det första gäller det fall att det framgår att den eftersöktes ansvar för samma gärning redan har prövats genom en lagakraftvunnen dom i en medlemsstat, under förutsättning av att straffet har avtjänats eller är under verkställighet eller inte längre kan verkställas enligt lagstiftningen i domslandet. Det andra fallet utgörs av ett fall då gärningen har prövats genom lagakraftvunnen dom i en annan stat än en i EU-stat, och detta enligt $10 \S$ tredje eller fjärde stycket lagen (1957:668) om utlämning för brott hade utgjort ett hinder mot utlämning av den eftersökte. ${ }^{48}$ Också det att gärningen omfattas av nåd eller ett annat beslut enligt 11 kap. $13 \S$ regeringsformen utgör ett utlämningshinder. ${ }^{49}$

Då det gäller överlämnande enligt den europeiska arresteringsordern har förundersökningsledaren i vissa fall fått en nyckelställning. Hinder mot överlämnande föreligger om förundersökning har inletts eller åtal har väckts i Sverige för en brottslig gärning och förundersökningsledaren motsätter sig att lagföringen sker i den medlemsstat som har utfärdat arresteringsordern. ${ }^{50}$ Fråga är om ett hinder mot överlämning som förutsätter en konkret rättslig in casu -bedömning av var lagföringen av ett visst brott bäst kan ske.

Skälen till att detta hinder har införts finns inte i en prioritering av att Sverige skall vara domstolsstat $\mathrm{i}$ alla de fall då brottet underlyder svensk straffrättslig jurisdiktion, utan i ett uttryckligt betonande av att den Europeiska unionen i jurisdiktionshänseende helst skall vara - och uppfattas vara - en enda jurisdiktion. I förarbetena till bestämmelsen konstateras bl.a. att utgångspunkten vid val av stat för lagföring skall vara att lagföringen sker i den stat där förutsättningarna för en materiellt riktig dom är bäst. Hur denna bedömning utfaller är bl.a. beroende av var bevisningen för brottet bäst kan tas upp. Överlämnande bör normalt inte heller ske om överlämnandet skulle äventyra eller försämra målsägandens möjligheter att söka utverka skadestånd från den som begärs överlämnad. I förarbetena hänvisas uttryckligen till Eurojusts uppgifter som ett gemensamt organ för brottskontroll inom hela Europeiska unionen. ${ }^{51}$ Det europeiska åklagarsamarbetets främsta syfte är att samordna utredningar som rör grov organiserad brottslighet 
med förgreningar i flera EU-medlemsstater och att utreda var en lagföring bäst kan ske. Eurojust kan bl.a. uppmana de rättsliga myndigheterna i medlemsstaterna att inleda lagföring eller att avstå från att lagföra, om det är lämpligare att de rättsliga myndigheterna i en annan medlemsstat lagför för ett visst brott. ${ }^{52} \mathrm{En}$ förutsättning för att en medlemsstat skall kunna åta sig att lagföra brottslighet som berör flera stater är som regel att andra stater som berörs av brottsligheten bistår den lagförande medlemsstaten med rättslig hjälp.

En skillnad mellan utlämning för brott och överlämnande, som är lätt att förstå och förklara, gäller möjligheterna att utlämna egna medborgare. Inom ett område som visserligen utgörs av flera stater men som politiskt förklarats utgöra ett enda område med fri rörlighet, och som betecknas som ett homogent område med frihet, säkerhet och rättvisa är det svårt att motivera att medborgare i skilda stater trots allt skall behandlas olika. De explicit uttalade intentionerna med att skapa ett område med frihet, säkerhet och rättvisa är bl.a. att brottsligheten överallt inom det europeiska området skall bekämpas "lika effektivt" och "på lika villkor". Att då särbehandla egna medborgare - t.ex. genom att förbjuda att de överlämnas till en annan stats rättssystem för lagföring för brott - är inte möjligt utan att bryta mot det överordnade politiska syftet. Det bör också noteras att möjligheten att utlämna egna medborgare mellan EU-staterna redan öppnades tidigare, genom konventionen av den 10 mars 1995 om ett förenklat förfarande för utlämning mellan Europeiska unionens medlemsstater. ${ }^{53}$

Trots den grundläggande uppfattningen om att det inte skall finnas någon skillnad mellan egna medborgare och medborgare i andra stater, innehåller ordningen med en europeisk arresteringsorder ett antal bestämmelser som ställer en egen medborgare i en särposition. Då det gäller den svenska regleringen kan följande nämnas: ${ }^{54}$

(a) Ett utlämningshinder av absolut karaktär föreligger i det fall, då påföljd av gärningen har bortfallit på grund av preskription, ${ }^{55}$ eller inte längre kan dömas ut enligt svensk lag ${ }^{56}$ och den eftersökte är svensk medborgare. ${ }^{57}$

(b) Då den som eftersöks genom en arresteringsorder är svensk medborgare, och ordern gäller verkställighet av en frihetsberövande påföljd, får överlämnande enligt huvudregeln inte beviljas om den eftersökte begär att påföljden skall verkställas i Sverige. ${ }^{58}$ Överlämnande får dock ske om den eftersökte vid tiden för gärningen sedan minst två år stadigvarande vistats i den utfärdande medlemsstaten. Men också i detta undantagsfall får överlämnande vägras om det med hänsyn till den eftersöktes personliga förhållanden eller av någon annan anledning finns särskilda skäl till att verkställighet av påföljden sker i Sverige. ${ }^{59}$

(c) Då den som eftersöks genom en arresteringsorder är svensk medborgare, och ordern gäller lagföring kan den eftersökte begära att verkställighet av en efter 
överlämnandet ådömd frihetsberövande påföljd skall ske i Sverige. ${ }^{60}$ Överlämnande får enligt huvudregeln i detta fall bara ske, om den utfärdande myndigheten lämnar garantier för att den eftersökte kommer att återföras till Sverige för verkställighet av en eventuell påföljd. Samma undantagsregeln finns som i fallet beskrivet ovan under punkt a. ${ }^{61}$

Hur kan dessa regler, som innebär en positiv diskriminering av egna medborgare, förklaras? Då det gäller särbehandlingen av en svensk medborgare på grund av preskription var det inte heller lätt för den svenska regeringen att finna en övertygande förklaring. I propositionen till lagen om överlämnande från Sverige enligt en europeisk arresteringsorder konstateras att överlämnande enligt rambeslutet får vägras om åtal för brottet eller verkställighet av straffet har preskriberats enligt den verkställande medlemsstatens lagstiftning. Det konstateras vidare att motsvarande bestämmelse finns i 1996-års konvention om utlämning mellan Europeiska unionens medlemsstater samt i den Europeiska utlämningskonventionen och i Schengen-konventionen.

Frågan om en särbehandling av svenska medborgare vid tillfälle av preskription i ett europeiskt sammanhang aktualiseras då Sverige skulle tillträda 1996-års konvention om utlämning mellan Europeiska unionens medlemsstater. Vid detta tillfälle bestämde man sig för en särreglering, också om man hade svårt att förena en sådan särreglering med de grundläggande principerna bakom konventionen. Regeringen anförde i den proposition som avsåg lagändringen, ${ }^{62}$ att det från en allmän utgångspunkt är rimligt att det är preskriptionstiden i den stat där brottet är förövat som skall vara avgörande för möjligheten att bevilja utlämning. Men eftersom utlämning av egna medborgare utanför Norden vid denna tidpunkt var en principiell nyhet, vars omfattning och konsekvenser bedömdes vara svåra att överblicka, "var [det] lämpligt att tills vidare alltjämt betrakta preskription som ett utlämningshinder för svenska medborgare." Någon ny bedömning gjordes inte i lagstiftningsärendet gällande arresteringsordern, trots att särbehandlingen av svenska medborgare i detta fall är ännu svårare att försvara på sakliga grunder.

De två andra fallen som innebär särbehandling av svenska medborgare gäller verkställighet av en frihetsberövande påföljd. Då en eftersökt person begär detta skall han (hon) enligt huvudregeln ha rätt att få verkställigheten av en frihetsberövande påföljd ordnad i Sverige.

De skäl som anförts för denna särbehandling utgår framför allt från att verkställigheten av frihetsberövande påföljder skall vara så human som möjligt, och så väl inriktad som möjligt på en integration av den frihetsberövade i det samhälle där han (hon) skall leva efter frigivningen. I förarbetena betonas att det främsta syftet med att överföra verkställighet av straff är att den dömde skall ges möjlighet att verkställa straffet där han kommer att friges eftersom den dömdes möjlighet till återanpassning är bättre om verkställigheten sker där han efter avtjänat straff 
skall leva och bo. Det konstateras också att det säger sig självt att permissionsgång och utslussningsåtgärder blir mindre meningsfulla om de äger rum i ett land som personen skall lämna efter avtjänat straff. Dessutom finns det ett humanitärt skäl till att överföra straffverkställighet till den dömdes hemland, eftersom den dömde då kommer att vistas på anstalter där hans eller hennes eget språk talas och där det finns möjlighet att ha regelbunden kontakt med anhöriga. ${ }^{63}$

Enligt rambeslutet kan överlämnande vägras både $\mathrm{i}$ ett fall då den eftersökte är medborgare i den verkställande staten och i det fall att han (hon) uppehåller sig i den. Sverige har i detta fall valt att begränsa möjligheten att vägra överlämnande till svenska medborgare. Med beaktande av de angivna skälen för denna särreglering verkar denna begränsning inte helt övertygande. De humanitära skäl och de skäl som finns i kriminalvårdshänseende talar ju uttryckligen för att alla - oberoende av medborgarskap - skall ha rätt till verkställighet $\mathrm{i}$ sin närmiljö. I förarbetena hänvisas till förbudet i RF (2 kap. 7 §) mot landsförvisning av svenska medborgare ${ }^{64}$, samt till en ordning med möjlighet att vägra överlämnande även av utländska medborgare som har anknytning till Sverige i praktiken är förenad med svåra överväganden. En ordning som möjliggör vägran också i fall som involverar i Sverige bosatta personer skull i vissa fall medföra att det blir svårare att överlämna än att utlämna en eftersökt person, och "detta skulle strida mot avsikten med rambeslutet." ${ }^{65}$

Det bör betecknas som anmärkningsvärt med tanke på det tidigare nordiska samarbetet att man inte i dessa fall har funnit och överenskommit om en gemensam nordisk linje. Som framgått har Danmark och Finland valt andra lösningar än Sverige och som innebär en mindre positiv diskriminering av egna medborgare.

Då det gäller andra omständigheter som traditionellt utgjort eller kunnat bli åberopade som utlämningshinder, kan det kort konstateras att det redan genom en ändring 2001 (2001:612) av lagen om utlämning för brott (6 § stycke 3 och 4) blev möjligt att utlämna för ett politiskt brott till en medlemsstat i Europeiska unionen. ${ }^{66}$ Enligt beaktandesatserna i rambeslutet om den europeiska arresteringsordern får ingen avvisas, utvisas eller utlämnas till en stat där han eller hon löper allvarlig risk att utsättas för dödsstraff, tortyr eller annan omänsklig eller förnedrande behandling eller bestraffning. Detta hinder mot överlämnande har i den svenska lagen upptagits genom att i den inta en hänvisning till Europakonventionen. ${ }^{67}$ Överlämnande får inte beviljas om det skulle strida mot den europeiska konventionen om skydd för de mänskliga rättigheterna och de grundläggande friheterna eller de tilläggsprotokoll till konventionen som gäller som lag i Sverige. ${ }^{68}$

Av betydelse i detta fall blir flera bestämmelser i Europakonventionen, t.ex. artikel 2 (rätten till liv), artikel 3 (förbudet mot tortyr), artikel 6 (kravet på en rättvis rättegång), artikel 8 (skydd för bl.a. privat- och familjeliv, artikel 9 (tankefrihet, 
samvets- och religionsfrihet), artikel 10 (yttrandefrihet). Också de artiklar som innehåller förbud mot diskriminering bör nämnas, framför allt artikel 14, som fastslår att åtnjutande av de fri- och rättigheter som anges i konventionen skall säkerställas utan någon åtskillnad såsom på grund av kön, ras, hudfärg, språk, religion, politisk eller annan åskådning, nationellt eller socialt ursprung, tillhörighet till nationell minoritet, förmögenhet, börd eller ställning i övrigt. Överlämnande får inte beviljas om det finns skäl att tro att det begärs i syfte att lagföra eller bestraffa den eftersökte på någon sådan grund.

Det bör konstateras att de svenska grundlagarna innehåller flera bestämmelser som har betydelse då det gäller att avgöra om ett hinder mot överlämning föreligger. Dessa fall gäller bland annat skyddet för föreningsfriheten och de frågor som sammanhänger med tryckfrihet och yttrandefrihet i media. Också immunitet och privilegier kan på samma sätt som vid utlämning innebära ett hinder mot överlämnande. ${ }^{69}$

\section{Strafftrösklar och kravet på dubbel straffbarhet}

Överlämnande enligt en europeisk arresteringsorder får enligt en huvudregel beviljas endast för en gärning som motsvarar brott enligt lagen i den stat som mottagit framställningen och som enligt den utfärdande medlemsstatens lagstiftning kan leda till en frihetsberövande påföljd i ett år eller mer eller, när överlämnandet avser straffverkställighet, för vilken en frihetsberövande påföljd i fyra månader eller mer har dömts ut. Från denna huvudregel finns dock väsentliga undantag. Det viktigaste är att det inte finns något krav på dubbel straffbarhet då det gäller de brottstyper som uppräknas i den s.k. "listan" - en lista som fogats till rambeslutet om arresteringsordern. Då det gäller brottstyper som nämns i listan och gärningen enligt den utfärdande medlemsstatens lagstiftning kan leda till en frihetsberövande påföljd $i$ tre år eller mer, skall överlämnande beviljas utan prövning av om gärningen motsvarar brott enligt svensk lag. ${ }^{70} \mathrm{Om}$ en begäran avser överlämnande för verkställighet av en frihetsberövande påföljd som har dömts ut för en gärning $\mathrm{i}$ listan, gäller det allmänna kravet på att en frihetsberövande påföljd i fyra månader eller mer har dömts ut. Ett ytterligare undantag från kravet på dubbel straffbarhet gäller vad som kallas accessoriskt överlämnande. När överlämnande beviljas i något fall med stöd av huvudregeln eller med stöd av reglerna om brotten $\mathrm{i}$ den s.k. listan får överlämnande även beviljas för annan gärning som motsvarar brott enligt svensk lag men som inte uppfyller kravet på svårhet eller, i fråga om en utdömd påföljd, kravet på att påföljden är av viss längd.

Under förarbetena till lagen om överlämnande från Sverige enligt en europeisk arresteringsorder konstaterades att arresteringsordern vilar på principen om ömsesidigt erkännande. Denna princip bygger i grunden på tanken att den rättsliga 
myndighet som initierar ett rättsligt förfarande skall förutsättas ha både god anledning och behörighet till detta. Myndigheter i andra medlemsstater skall godta den begärande myndighetens bedömningar. Detta innebär också att avskaffandet av dubbel straffbarhet är ett naturligt och konsekvent inslag. Med hänvisning till principen om ömsesidigt erkännande skall man inte bara acceptera det som ett faktum att en lagföring i ett konkret fall har inletts i en annan stat på goda grunder och genomförts på ett sätt som är fullt lagligt och rättvist. Man skall också acceptera att kriminaliseringsbesluten som sådana i denna stat är väl övervägda och att straffen för de kriminaliserade gärningarna i denna stat är rationella och rättvisa. Det ömsesidiga förtroendet skall alltså gälla hela straffsystemet.

I detta skede stannade man trots allt för att upphäva kravet på dubbel straffbarhet bara för de brottstyper som finns upptagna på den s.k. listan, samt vid de fall som utgörs av accessoriskt överlämnande. Det rättspolitiskt intressanta är om ens en sådan eftergift när det gäller kravet på dubbel straffbarhet är väl motiverad.

Den grundläggande utgångspunkten är fortfarande att utformningen av det nationella straffsystemet primärt är en inre angelägenhet för varje stat. Det innebär också att besluten att kriminalisera en gärning i grunden är nationella beslut. Det är den nationella lagstiftaren som beslutar om vilka gärningar det är som skall straffbeläggas och hur strängt straffet för respektive brottstyp skall vara. Det europeiska straffsystem som numera finns inom Europeiska unionen innebär inte att man har övergett denna grundläggande utgångspunkt.

Det finns betydande skillnader mellan vad som är kriminaliserat som brott i de olika medlemsstaterna inom Europeiska unionen och också när det gäller de straff och påföljder som kan utdömas för olika brott. I förarbetena till lagen om överlämnande från Sverige enligt en europeisk arresteringsorder konstateras att skillnaderna i kriminalisering många gånger kan förklaras av att olika länder har olika behov, beroende på t.ex. att en viss typ av brottslighet är vanlig i det landet. Detta är riktigt. Det faktiska kriminaliseringsbehovet av en viss gärning kan variera beroende t.ex. på de ekonomiska, sociala eller de mer generella samhälleliga förhållandena. Men det är lika viktigt att konstatera att det också finns en genuin oenighet om vad det är som skall kriminaliseras som brott - en oenighet som bygger på varierande ideologiska och värdemässiga bedömningar. I vissa stater anser man helt enkelt att det är fel att kriminalisera vissa gärningar som är kriminaliserade $\mathrm{i}$ andra stater.

I förarbetena till lagen om överlämnande från Sverige enligt en europeisk arresteringsorder konstateras också att skillnaderna mellan lagstiftningen i skilda stater också kan vara närmast lagteknisk till sin natur. Som exempel nämns att ansvaret för försök och förberedelse till ett visst brott kan ha olika utformning i olika medlemsstater. Detta gäller bl.a. brottet "deltagande i en kriminell organi- 
sation", som finns i den s.k. listan. Deltagande i en sådan organisation kan t.ex. vara förberedelse eller försök till ett grovt brott enligt svensk rätt, medan det $\mathrm{i}$ andra länder betecknas som ett självständigt brott.

Också denna observation är riktig, men den kan inte åberopas som ett gott skäl för att avstå från kravet på dubbel straffbarhet. Bedömningen av detta krav skall göras konkret. Kan straffansvar utdömas i det konkreta fallet både i staten A och i staten B? Om detta kan ske är kravet på dubbel straffbarhet uppfyllt oberoende av att straffbestämmelserna som tillämpas är olika och bygger på skilda tekniska lösningar. Om straffansvar inte kan utdömas är kravet inte uppfyllt och detta är i så fall en konsekvens av att man gjort olika rättspolitiska bedömningar i de två berörda staterna. I den ena har man helt enkelt inte önskat utsträcka straffansvaret lika långt som i den andra staten.

I förarbetena till lagen om överlämnande från Sverige enligt en europeisk arresteringsorder hänvisas till att alla brott som finns på den s.k. listan är typiskt sett sådana brott som är kriminaliserade i alla EU:s medlemsstater. Detta är förmodligen riktigt. Men problemet med listan är att brottstyperna i listan inte är exakt beskrivna eller på annat sätt precist angivna. Brottstyperna som upptas på listan beskrivs bara genom en uppräkning där de beskrivs genom en benämning, t.ex. "deltagande i en kriminell organisation, terrorism, människohandel etc.

Denna tämligen oprecisa lista har med fullt fog kritiserats på grund av att det förblir osäkert vilka brottstyper som med stöd av listan de facto är sådana att kravet på dubbel straffbarhet inte gäller. Det har hävdats att överlämnande för brott enligt listan är förenat med godtycke och bristande förutsebarhet.71

Kravet på dubbel straffbarhet kan framför allt ses som en rättssäkerhetsgaranti för en person som anklagas för brott. Detta krav har uppställts som förutsättning för bestraffning av ett utomlands begånget brott framför allt i det fall då domstolsstatens jurisdiktion över brottet bygger på den aktiva personalitetsprincipen. Kravet på dubbel straffbarhet har också uppställts som en av de traditionella förutsättningarna för att utlämna för brott. Också i vissa andra fall som gäller internationell rättslig hjälp har detta krav uppställt för beviljande av rättslig hjälp.

Man kan fråga sig om det är lika viktigt att detta krav uppställs som en rättssäkerhetsgaranti i alla dessa fall. Det kan ligga nära till hands att anse att kravet är viktigast då det gäller bestraffning av ett brott som begåtts utomlands. Det kan förefalla stötande - också med hänvisning till den straffrättsliga legalitetsprincipen - att bestraffa en person med stöd av domstolsstatens strafflag för en gärning som var tillåten på den ort där den begicks. Att utlämna eller överlämna en för brott anklagad person från en stat där den gärning som han anklagas för inte är ett brott till en stat där han begick gärningen och där den är ett brott förefaller mindre stötande. 
Trots detta kan man anföra goda skäl för att upprätthålla kravet på dubbel straffbarhet också i sistnämnda fall. Den grundläggande frågan är om en stat verkligen aktivt skall bidra till att en person bestraffas eller att ett utdömt straff verkställs för en gärning som i denna stat inte uppfattas vara brott? Låt mig belysa detta med ett exempel. Vi kan anta att en svensk medborgare begärs utlämnad till en annan medlemsstat för ett sådant brott som finns upptaget på den s.k. listan och för vilket det i den stat där arresteringsorderna har utfärdats kan utdömas ett straff som är strängare än tre år frihetsstraff. Denna gärning är inte brott enligt svensk lag, varför kravet på dubbel straffbarhet inte är uppfyllt. Den som begärs bli överlämnad utnyttjar sin rättighet att kräva att ett frihetsstraff som möjligen utdöms skall verkställas i Sverige. Skall man då ta in en svensk medborgare i ett svenskt fängelse för en gärning som inte är brott i Sverige och verkställa ett möjligen långt frihetsstraff här?

Genom antagandet av den ordning som gäller för den europeiska arresteringsordern besvaras denna fråga jakande. I förarbetena fastslås att vad som är viktigare än att upprätthålla ett krav på dubbel straffbarhet är att en person som är eftersökt för grova brott inte undgår lagföring eller straff på grund av att medlemsstaternas kriminalisering av brotten i "listan" skiljer sig åt. Det konstateras att de gärningar som det i praktiken handlar om typiskt sett utgörs av grov brottslighet. Det ifrågasätts "varför en medlemsstat skall kunna vägra överlämna en eftersökt person bara för att en annan medlemsstat har kriminaliserat vissa gärningar på ett delvis annorlunda sätt.” Detta argument kan bemötas med att fråga i verkligheten också kan vara om överlämnande för en gärning som en stat medvetet, av ideologiska och rättspolitiska skäl, har bestämt sig för att inte straffbelägga.

\section{Den praktiska tillämpningen av arresteringsordern}

Ordningen med den europeiska arresteringsordern blev snabbt ett viktigt och ofta använt sätt för överföring av brottsmisstänta och brottsdömda personer från stat till annan inom EU. De offentligt tillgängliga uppgifterna om hur många överföringar som årligen sker med stöd av ordningen och vilka fall som dessa avser är dock begränsade. Sett ur ett effektivitetsperspektiv kan den europeiska arresteringsordern därför betecknas som ett framsteg jämfört med den tidigare ordningen med traditionell utlämning för brott. Ur ett rättssäkerhetsperspektiv blir bedömningen av ordningen inte lika positiv. Som granskningen ovan visar kan man på ett antal punkter ställa sig tvekande eller kritisk till den ordning som man har valt för att med tvångsmakt förflytta människor från en stat till en annan. I viss utsträckning kan också den europeiska arresteringsordern ses som ett led i det skifte av idealmodellen för straffrättslig rättskipning och brottmålsrättegång som allt tydligare förefaller bli realiserad. Det som gäller är inte längre en rättssäkerhetsmodell 
med betoning av rättssäkerhet och rättsliga garantier, utan en kontrollmodell med betoning av effektivitet. Det är en allvarlig tendens att brottsbekämpningsresonemanget har blivit så dominerande och att rättsskyddsargument inte längre har samma slagkraft som tidigare. ${ }^{72}$

\section{Noter:}

Se för en utförligare beskrivning Per Ole Träskman: Vad gör vi med den europeiska kriminalpolitiken? SvJT 2005, s 859-862.

2 Se Anne Weyembergh: The Functions of Approximation of Penal Legislation within the European Union. Maastricht Journal of European and Comparative Law 2005, Volume 12, Number 2, s 149-172. Se också Dan Frände: Towards a Harmonized Criminal Justice System in the EU. I Frände \& Liukkunen \& Sankari \& Storskrubb: In the Footsteps of Tampere. Justice in the European Union. Helsinki 2006, s 35-50.

3 Träskman i fotnot 1 a.a., s 862-863 och Frände i fotnot 2 a.a., s 43-44.

$4 \quad$ Träskman i fotnot 1 a.a., s 863-865.

5 Se för en samlad bedömning Matti Joutsen: The European Union and Cooperation in Criminal Matters: the Search for Balance. The European Institute for Crime Prevention and Control, affiliated with the United Nations. HEUNI-papers No. 25. (2006), s 20-22.

6 Se prop. 2003/04:7 Lag om överlämnande från Sverige enligt en europeisk arresteringsorder, s 1, samt prop. 2001/02:118, bet. 2001/02:JuU29, rskr 2001/02:256.

7 Lov nr. 433 af 10. juni 2003 om ændring af lov om udlevering af lovovertrædere og lov om udlevering af lovovertrædere til Finland, Island, Norge og Sverige (gennemførelse af EU-rammeafgørelse om den europæiske arrestordre mv.) Se också Jørn Vestergaard: Udlevering til strafforfølgning mv. - den europæiske arrestordre som udtryk for gensidig anerkendelse. Festskrift til Hans-Gammeltoft Hansen. København 2004, s 627-653. En terminolgisk skillnad bör uppmärksammas: I Sverige används i detta sammanhang termen "överlämnande", medan man i den danska och finska terminologin också då det gäller den europeiska arresteringsordern talar om "utlämning".

8 Per Ole Träskman: Strafflagen för Europeiska Unionen - Fakta och fiktion. SvJT 2002, s 348-358.

9 I preambeln till rambeslutet omnämns särskilt följande konventioner och överenskommelser: Europeiska utlämningskonventionen av den 13 december 1957, konventionen av den 19 juni 1990 om tillämpning av Schengenavtalet av den 14 juni 1985 om gradvis avskaffande av kontroller vid de gemensamma gränserna mellan de medlemsstater som är anslutna till konventionen, konventionen av den 10 mars 1995 om ett förenklat förfarande för utlämning mellan Europeiska unionens medlemsstater och konventionen av den 27 september 1996 om utlämning mellan Europeiska unionens medlemsstater. I tillägg omnämns den Europeiska konventionen om bekämpande av terrorism av den 27 januari 1977 samt de särskilda regler som finns för utlämning mellan de Nordiska länderna.

10 Lag om överlämnande från Sverige enligt en europeisk arresteringsorder, 1 kap. 3 §.

11 Se också Annika Suominen: Ömsesidigt erkännande av rättsliga beslut som hörnsten i det europeiska straffrättsliga samarbetet. JFT 2006, s 607-616.

12 Se rambeslutet artikel 9, samt prop.2003/04:7, s 103-105.

13 Den finska lagen $12 \S$.

14 Justitieministeriet var sedan tidigare beslutande myndighet i utlämningssaker. Se Justitsministeriets Vejledning om behandlingen af anmodninger om udlevering af lovovertrædere på grundlag af en europæisk arrestordre, 2.3.

15 Se rambeslutet artikel 1 och artikel 12, samt prop. 2003/04:7, s 109-113. 
Rambeslutet artikel 11:2.

I Danmark har den eftersökte rätt till en försvarare med stöd av en bestämmelse i utlämningslagens $\S 14$, i Finland har den eftersökte rätt till en försvarare om han/hon begär det; den finska lagen $20 \S$.

Rambeslutet artikel 6.

Justitsministeriets vejledning (se fotnot 13), 2.3.2.1.

Den finska lagen $11 \S$.

Justitsministeriets vejledning, 2.3.5.

Den finska lagen 29 och $30 \S \S$.

Den finska lagen 7 §.

Den som inte har fyllt arton år får anhållas endast om det finns synnerliga skäl.

Lag om överlämnande från Sverige enligt en europeisk arresteringsorder 4 kap. $5 \S$. Också enligt den danska lagen och den finska lagen kan den eftersökte berövas friheten under undersökningen, se Justititsministeriets vejledning, 2.3.2. och den finska lagen $16-19 \S \S$.

Rambeslutet artikel 17:1.

Enligt den danska kagen skall justitieministeriet så vitt möjligt besluta om överlämnande inom 10 dagar räknat från den dag då den eftersökte har gett sitt samtycke till överlämnandet eller blivit anhållen med stöd av arresteringsordern. Tiden förlängs om den eftersökte önskar få avgörandet prövat vid domstol. Överlämnandet bör i dessa fall ske inom 60 dagar röknat från nämnda tidpunkt. Justitsministeriets vejledning, 2.3.4.1. I Finland skall tinsgrätten fatta sitt beslut inom tre dagar räknat från möjligt samtycke av den eftersökte samt alltid inom 26 dagar från den dag då den eftersökte greps eller påträffades i Finland. Den finska lagen $32 \S$.

Lag om överlämnande från Sverige enligt en europeisk arresteringsorder 2 kap. $1 \S$.

Ibidem 7 kap. 3 §.

Se närmare Karin Påle: Villkor för utlämning. Uppsala 2003, särskillt s 378-387.

För utlämning mellan de Nordiska staterna gäller särskild bestämmelser. Se lagen (1959:254) om utlämning för brott till Danmark, Finland, Island och Norge. Dessa behandlas ej systematiskt här. Se lagen om utlämning för brott 9 §.

Se beträffande motsvarande villkor i Danmark Vestergaard i fotnot 7 a.a., s 634-639.

Lagen (1959:254) om utlämning för brott till Danmark, Finland, Island och Norge 5 §: "För gärningar som nämns i de föreskrifter i $16 \mathrm{kap}$. brottsbalken som avser brott av krigsman eller i 21 kap. brottsbalken eller i lagen (1994:1809) om totalförsvarsplikt får utlämning inte medges, om inte annat följer av en internationell överenskommelse som är i kraft mellan Sverige och den ansökande staten."

35 Se lagen om utlämning för brott $6 \S$ : "Utlämning får inte beviljas för ett politiskt brott. Innefattar gärningen även ett brott som inte är politiskt, får utlämning beviljas för det brottet, om gärningen i det särskilda fallet övervägande har karaktären av ett icke politiskt brott.” Ibidem $10 \S$.

Det bör nämnas att också det faktum, att den person vars utlämning som begärs är misstänkt eller är dömd för ett annat brott än det som utlämningsbegäran avser, kan utgöra ett tillfälligt utlämningshinder. Enligt lagen om utlämning för brott (11 §) får den som är åtalad för annat brott, för vilket är stadgat fängelse, eller som enligt dom mot honom (eller henne) skall undergå fängelse eller eljest omhändertagas på anstalt, inte utlämnas så länge som hindret består. Detta gäller också då en förundersökning har inletts för sådant brott.

Lgen om utlämning för brott $8 \S$.

Ibidem $7 \S$.

Ibidem 12 .

I avsnittet om “[p]ropositionens huvudsakliga innehåll” i prop. 2003/04:7 (s 2) kan man bl.a. läsa att "[i] lagen anges i vilka fall överlämnande skall beviljas. Dessa motsvarar i stora delar 
vad som gäller vid utlämning", samt att "[i] lagen finns motsvarigheter till flera av utlämningslagens avslagsgrunder. Enligt rambeslutet är vissa av avslagsgrunderna tvingande och andra inte tvingande." Denna beskrivning är i och för sig riktig, men samtidigt underskattas i detta fall skillnaderna mellan utlämning och överlämnande klart.

Man kan ifrågasätta om den intention som uttrycks i förarbetena då gäller explicit reglering verkligen har realiserats: "Regeringen anser därför att det i den nya lagen uttryckligen bör anges under vilka förutsättningar överlämnande får ske samt när överlämnande skall eller får vägras." Prop 2003/04:7, s 68.

43 Lag om överlämnande från Sverige enligt en europeisk arresteringsorder 2 kap. $5 \S$ punkt 7 .

44 Motsvarande bestämmelse ingår både $\mathrm{i}$ den danska (se justitsministeriets vejledning, 2.2.2.) och i den finska lagen (se den finska lagen $5 \S$ punkt 5).

45 Motsvarande bestämmelser finns också i den danska och den finska legen.

46 Lag om överlämnande från Sverige enligt en europeisk arresteringsorder 2 kap. $5 \S$ punkt 1 .

47 Lag om överlämnande från Sverige enligt en europeisk arresteringsorder 2 kap. $5 \S$ punkt 2 .

48 Ibidem 2 kap. $5 \S$ punkt 3 och 4 . Se också justitsministeriets vejledning, 2.2.2. och den finska lagen $5 \S$ punkt 3 ).

49 Se beträffande motsvarande bestämmelser i dansk och finsk rätt justitsministeriets vejledning 2.2.2. och den finska lagen $5 \S$.

50 Lag om överlämnande från Sverige enligt en europeisk arresteringsorder 2 kap. $5 \S$ punkt 5 . Motsvarande reglering finns i Danmark (justitsministeriets vejledning, 2.2.2.).

51 Prop. 2003/04:7, s 83-85.

$52 \quad$ Prop. 2001/02:86, bet. 2001/02:JuU19, rskr. 2001/02:159.

53 I samband med Sveriges tillträde till denna konvention anfördes följande skäl för att tillåta utlämning av svenska medborgare till andra EU-stater (prop. 2000/01:88 s. 30 ff): "Den minskade gränskontrollen i förening med en ökad rörlighet över gränserna inom Europa är faktorer som underlättar för den internationella brottsligheten att breda ut sig. Sannolikt är det många gånger en slump i vilket land en misstänkt person grips. Rättegångar med personer från olika länder inblandade kan också förväntas bli vanligare. En annan följd av den ökade internationella rörligheten är att begreppen medborgarskap och hemvist inte längre är lika naturligt förknippade med varandra. Att vara medborgare i en stat och ha hemvist $\mathrm{i}$ en annan är idag inte något ovanligt. Mot den nu tecknade bakgrunden ter det sig inte rimligt att en svensk medborgare som bott en längre tid i en annan EU-stat och där gjort sig skyldig till brott skall kunna undvika lagföring i den staten genom att resa till Sverige. Rättigheten inom EU att bo och arbeta i ett land där man inte är medborgare bör också innebära en skyldighet att i vissa fall underkasta sig det andra landets regler och jurisdiktion." Beträffande motsvarande grunder för förvägrande av överlämnande i den danska lagen då den eftersökte är dansk medborgare, se Vestergaard i fotnot 7 a.a., s 639-641.

55 Jfr BrB 35 kap. 8 §.

56 Jfr BrB 35 kap. 1 §.

57 Lag om överlämnande från Sverige enligt en europeisk arresteringsorder 2 kap. $5 \S$ p. 6 . Det bör noteras att de danska och finska bestämmelserna om verkan av preskription inte begränsas till egna medborgare. I Danmark utgör det en fakultativ grund att vägra överlämnande då "den pågældende strafbare handling er omfattet af dansk straffemyndighed, og strafansvaret eller adganngen til at fuldbyrde straf for den pågældende handling ville være forældet efter dansk ret”. Justitsministeriets vejledning, 2.2.2. I Finland kan överlämnande förvägras om åtalsrätten för brottet har preskriberats enligt finsk lag, eller om straff inte längre skulle kunna dömas ut eller verkställas och finsk lag kan tillämpas på gärningen enligt reglerna om jurisdiktion. Den finska lagen 6 § punkt 5 , se också 5 § punkt 5 b).. 
59 När en svensk medborgare begärs överlämnad för verkställighet av en frihetsberövande påföljd, skall åklagaren eller, på uppdrag av åklagaren en polisman som biträder vid utredningen, fråga den eftersökte om han eller hon begär att påföljden skall verkställas i Sverige. Den eftersökte skall upplysas om innebörden av att påföljden verkställs i Sverige. För de två fall då svensk medborgare ställs i en särställning finns också vissa andra särskilda regler närmast av formell karaktär.

Enligt den danska lagen skall överlämnande förvägras i ett fall då "straffuldbyrdelse vedrørende en person, der er dansk statsborger eller har fast bopæl her i alndet, findes at burde ske her i landet". Justitsministeriets vejledning 2.2.2. Enligt den finska lagen skall överlämnande förvägras om framställningen gäller verkställighet av frihetsstraffr och den som begärs utlämnad är finsk medborgare och anhåller om att få avtjäna frihetsstraffet i Finland. Den finska lagen $5 \S$ punkt 4). Lag om överlämnande från Sverige enligt en europeisk arresteringsorder 3 kap. 2 .

${ }_{61}$ Enligt den danska lagen är det en fakultativ avslagsgrund att den "udenlandske myndighed ikke vil acceptere et vilkår om, at en person, der er dansk statsborger eller har fast bopæl her i landet, alene kan udleveres til strafforfølgning, hvis den pågældende overføres til Danmark med henblik på fuldbyrdelse af en eventuel fængselstraf. Justitsministeriets vejledning, 2.2.2. I Finland skall som villkor för överlämnande av finsk medborgare uppställas att den utlämnade omedelbart efter att domen har vunnit laga kraft återsänds till Finland för att avtjäna ett eventuellt frihetsstraff som har dömts ut, om personen ifråga i samband med behandlingen av ärendet har anhållit om att få avtjäna straffet i Finland. Detta gäller också en person som är varaktigt bosatt i Finland om det på grund av hans eller hennes personliga förhållanden eller av något annat särskilt skäl är motiverat att ett eventuellt frihetsstraff får avtjänas i Finland. Se den finska lagen 8 §. Prop 2000/2001:83, s 34 .

Prop. 2003/04:7, s 94-95.

"[...] utlämning av en svensk medborgare, som innebär en mycket långvarig fängelsevistelse för den som utlämnas, torde vara att jämställa med landsförvisning (prop. 1975/76:209 s.

121, bet. 1975/76:KU56 s. 32). Motsvarande hinder finns inte vid utlämning av utländska medborgare.[...]”. Detta är ett argument som knappast håller. Svenska medborgare har kunnat utlämnas till ett annat nordiskt land under flera decennier, utan att argumentet har åberopats.

65 Prop. 2003/04:7, s 95.

66 Se 1995 -års konvention om ett förenklat förfarande för utlämning mellan Europeiska unionens medlemsstater, art. 5, som föranledde den svenska lagändringen.

67 I den finska lagen har man intagit en explicit bestämmelse med detta innehåll, $5 \S$ punkt 6 ).

68 Lag om överlämnande från Sverige enligt en europeisk arresteringsorder 2 kap. 4 § punkt 2.

$69 \quad$ Ibidem 2 kap. 4 § punkt 3.

70 Det bör särskillt noteras att det enligt rambeslutet är förbjudet för en medlemstat att uppställa krav på dubbel straffbarhet då det gäller brottstyper som finns upptagna på listan. Borttagandet av kravet på dubbel straffbarhet innebär i praktiken att det är den utfärdande statens straffrättsliga definition av brottet som skall tillämpas. Därigenom förenklas förfarandet genom att någon bedömning inte krävs av om den aktuella gärningen motsvarar ett brott $\mathrm{i}$ den verkställande staten.

71 Se Vestergaard i fotnot 7 a.a., s 642-646.

72 Se också Per Ole Träskman: Brottsligheten och dess bekämpande - en refleksion om verkliga hot och hotbilder. SvJT 2007, s 109- 110. 